\title{
SERUM ANTILEPTOSPIRAL AGGLUTININS IN FRESHWATER TURTLES FROM SOUTHERN BRAZIL
}

\author{
Éverton F. Silva $^{1,2+*}$; Núbia Seyffert ${ }^{1,2+}$; Gustavo M. Cerqueira² ${ }^{2}$ Karl P. Leihs ${ }^{1}$; Daniel A. Athanazio ${ }^{3}$; \\ Ana L. S. Valente ${ }^{4}$; Odir A. Dellagostin ${ }^{2}$; Claudiomar S. Brod ${ }^{1}$ \\ ${ }^{1}$ Centro de Controle de Zoonoses, Universidade Federal de Pelotas, Pelotas, RS, Brasil; ${ }^{2}$ Centro de Biotecnologia, \\ Universidade Federal de Pelotas, Pelotas, RS, Brasil; ${ }^{3}$ Universidade Federal da Bahia, Salvador, BA, Brasil; \\ ${ }^{4}$ Departamento de Morfologia, Instituto de Biologia, Universidade Federal de Pelotas, Pelotas, RS, Brasil.
}

Submitted: March 10, 2008; Returned to authors for corrections: March 18, 2008; Approved: March 06, 2009.

\begin{abstract}
In this study, we observed the presence of antileptospiral agglutinins in freshwater turtles of two urban lakes of Pelotas, Southern Brazil. Forty animals (29 Trachemys dorbigny and 11 Phrynops hilarii) were captured and studied. Attempts to isolate leptospires from blood and urine samples were unsuccessful. Serum samples (titer $>100$ ) reactive to pathogenic strains were observed in 11 animals. These data encourage surveys of pet turtles to evaluate the risk of transmission of pathogenic leptospires to humans.
\end{abstract}

Key words: Leptospirosis; Turtles; Agglutinins.

Leptospiral strains are broadly distributed in soil and water worldwide. Pathogenic leptospires infect humans and animals by direct or indirect contact with contaminated urine. Most severe forms of human leptospirosis present as the Weil's triad of jaundice, renal failure and hemorrhages; or pulmonary hemorrhage. Human infections are commonly related to outbreaks after floods in urban areas with poor sanitation and to occupational risk (sewer, farm and rice field workers). In these settings, rodents and farm animals are the most important sources of infection. The list of natural reservoirs of pathogenic leptospires, however, is extensive and continues to grow (3). The role of reptiles and other poikilothermic vertebrates as sources of pathogenic leptospires has been historically neglected (5). In particular, turtles harbor some human pathogens such as Salmonella (11) and a leptospiral pathogenic serovar (Tarassovi) has been already isolated from kidney tissue of red-eared turtles (Pseudemys scripta-elegans) and from the surface water collected from the settling ponds of sewage disposal system where these animals lived (7). These findings are relevant in the light of the recent interest on the exposure risk to leptospires during recreational activities (3), and the risk of using these animals as pets (11).
Forty freshwater turtles were trapped in Pelotas city from two public lakes: the first lake is located next to the bus station and the second is inside the Coronel Pedro Osório Park. Both places distance several miles from each other and are eventually used for baths by homeless individuals and by young adults in recreational activities. Pelotas is a coastal and populous city (> 400,000 inhabitants) of Rio Grande do Sul, a state that has 11 million inhabitants and a typical temperate climate. However, the incidence of human leptospirosis is higher than the mean incidence of states with tropical climate ( 12.5 vs. 3.5 per 100,000 inhabitants in 2001). Pelotas had an annual incidence of $>50$ cases per 100,000 inhabitants in 2001 , being one of the 17 municipalities with a significantly high rate compared to the mean incidence of the state (2).

Twenty-nine animals were identified as Trachemys dorbigny and eleven as Phrynops hilarii. Serum samples were obtained by jugular puncture and then investigated for the presence of antileptospiral agglutinins. The microscopic agglutination test (MAT) was performed according to standard methods (5). The cutoff titer of $>1: 100$ was considered as the minimum reactive. Live antigens included 32 reference pathogenic strains

*Corresponding Author. Mailing address: Universidade Federal de Pelotas. Centro de Biotecnologia. Campus Universitário s/n. Caixa Postal 354. CEP 96010-900. Pelotas, RS, Brasil. Tel.: +55 53 32757587; Fax: +55 53 32757551. E-mail address: efsilva@ufpel.edu.br

$\dagger$ These authors contributed equally to this work. 
belonging to 28 serovars of 19 serogroups (Australis, Autumnalis, Ballum, Bataviae, Canicola, Celledoni, Cynopteri, Djasiman, Grippotyphosa, Hebdomadis, Icterohaemorrhagiae, Javanica, Lousiania, Mini, Pomona, Pyrogenes, Sejroe, Shermani, Tarassovi). Reference saprophytic strains included 7 strains belonging to 5 serogroups (Andamana, Doberdo, Garcia, Pulpudeva, Seramanga) and Leptonema illini. Pathogenic local isolates belong to the following serogroups: Australis (strains Hook and Skoll), Autumnalis (Bonito), Bataviae (Cascata), Canicola (Tande; Kito), Djasiman (Isoton). All strains were grown in Ellinghausen-McCullough-Johnson-Harris (EMJH) liquid medium supplemented with $10 \%$ rabbit serum at $29^{\circ} \mathrm{C}$ for seven days until use.

An attempt to isolate leptospires was performed using turtle fluids. Sixteen blood samples and 8 urine samples from 16 randomly selected turtles were inoculated in $5 \mathrm{~mL}$ of Fletcher semi-solid medium, without antibiotics. Blood evaluation was based on the previous observation that leptospires could be recovered from liver tissue of reptiles (snakes) up to 195 days after experimental infection (1). The cultures were incubated at $29^{\circ} \mathrm{C}$ for 7 weeks and examined weekly by darkfield microscopy. All procedures performed in these animals were approved by the Brazilian Institute of Renewable Natural Resources (IBAMA-Brazil). Despite several attempts to isolate leptospires from turtle samples, no positive cultures were obtained.

All forty serum samples were reactive by MAT in dilutions $<1: 100$. Positive reactions (defined as titers $>100$ ) occurred regardless the species (T. dorbigny $10 / 29,34 \%$, versus P. hilarii $1 / 11,9.1 \%$ ) or gender, age and site of capture, and none of the differences were significant. Positive samples reactive to pathogenic strains were observed in 11 animals (27.5\%) and 9 of them had titers $\geq 320$ (Table 1 ).

Serum samples from $72.7 \%$ (8/11) of the positive turtles had the highest MAT titer against a single strain, $18.2 \%(2 / 11)$ for two strains, and $9.1 \%(1 / 11)$ reacted similarly against three strains. The most common predicted infecting serogroup was Bataviae, specifically due to reactions with a local isolate (Leptospira noguchii strain Cascata), representing 63.7\% (7/ 11) of the seropositive turtles (Table 1). The highest titer at which agglutination was observed was 5,120 in one case for serogroup Bataviae (strain Cascata) and in one case for serogroup Tarassovi (strain Perepelicin). The distributions of MAT titers in 12 turtles with positive serologic reactions are presented in Table 1. Only one case had positive MAT exclusively for saprophytic Leptonema illini. Cross reactions between pathogenic and saprophytic serogroups were observed only in two cases.

In our study, $27.5 \%$ of turtle serum samples were positive by MAT for pathogenic strains, with titers ranging from 160 to 5,120 . The major drawback of the present study was the failure to isolate leptospires from chelonian body fluids. Previous data from serologic surveys of anti-leptospiral agglutinins also reported that culture isolation is difficult in these animals (15). Indeed, the unique report of microbiologic isolation of pathogenic leptospires from turtles (kidney and cloacal) required indirect (in vivo) growth in hamster to recover serovar Tarassovi (7).

Our serologic survey detected high serum titers of agglutinins anti-leptospires with relatively low cross reaction rates. Infections predicted by MAT were mainly attributable to serogroup Bataviae $(63.7 \%, \mathrm{n}=7)$ and the strain used in our MAT panel was Cascata (L. noguchii), a local clinical isolate. We did not observe reactions against the reference serovar Bataviae, strain Van Tienen, however, it must be pointed out that strain Cascata has not been characterized to the serovar level and its antigenic relatedness with serovar Bataviae is unknown. All these cases were associated with $T$. dorbigny. The second serogroup with more frequent reactions was Tarassovi $(27.2 \%, \mathrm{n}=3)$, an interesting finding since it was the only one serovar isolated from turtles until now (7). On the other hand, only one reactive sample $(9.1 \%)$ was found for serogroup Icterohaemorrhagiae (serovar Copenhageni) (Table 1 ), which is mainly carried by rats and is the major cause of severe human leptospirosis in urban areas of Brazil (10).

The combination of high serum titers of agglutinins, failure to isolate leptospires and high degree of cross reaction with saprophytic strains has already led to the suggestion that agglutination in these animals could be attributed to natural serum factors other than antibodies $(4,15)$. It is important to highlight that natural occurring humoral factors that agglutinate leptospires also occur in mammals, including humans $(6,9)$. Moreover, among turtles whose serovar Tarassovi was isolated, high MAT titers for serovar Tarassovi exhibited considerable cross reaction with three saprophytic strains (7). Cross agglutination with saprophytic strains have also been observed in Brazilian snakes including those where leptospires could be isolated from $(8,12)$. An evidence that MAT is a valid tool for survey of leptospiral infection in turtles is the experimental observation that two species (Emydoidea blandingi and Chelydra serpentina) exhibited homologous seroconversion after infection by serovar Pomona (1).

The present study is the first report of serological survey of freshwater turtles in Brazil. Of relevance, both evaluated species are abundant in Brazilian lakes (13) and allow us to infer that they may act as reservoir of pathogens. Our failure to isolate leptospires may be partially explained by the absence of antibiotics or growth inhibitors, as 5-fluorouracil, in the Fletcher medium; and by the impossibility of using hamster model for indirect isolation. The methodology employed in this study, however, has already allowed us to isolate leptospires from other sources (14).

In conclusion, we report the occurrence of antileptospiral agglutinins in freshwater turtles. Based on the results presented here, we believe that several points highlight the potential 
Table 1. Positive tests in freshwater turtles.

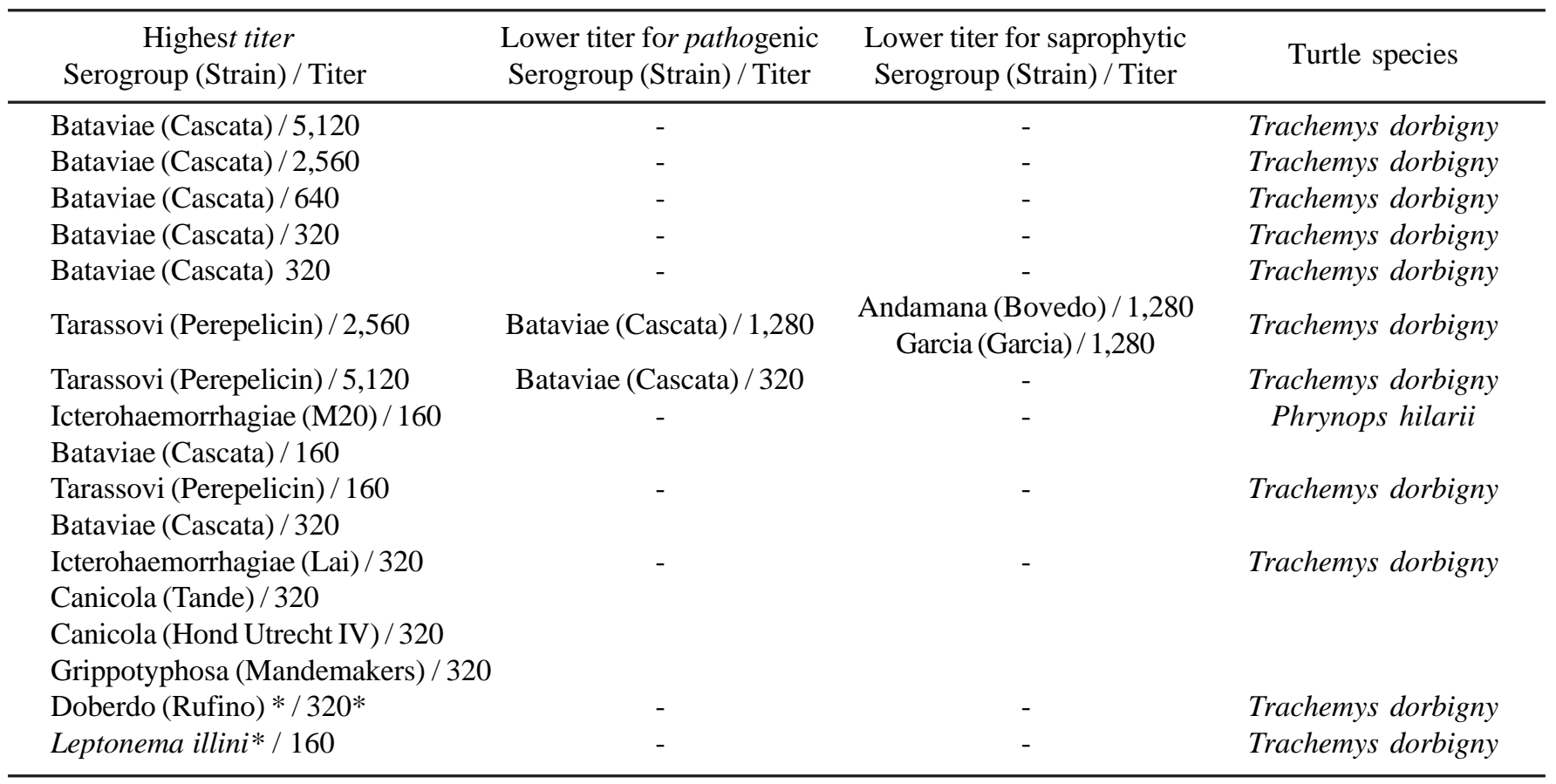

* regarded as non pathogenic.

infection in these animals: 1) MAT titers as high as 5,120 and the low degree of cross agglutination with other pathogenic and saprophytic strains are not indicative of unspecific broadly reactive natural agglutinins; 2) The relatively low frequency of positive animals suggests sporadic exposure to leptospires; and 3) The most common predicted infecting serogroup also include a clinical human isolate recently obtained in Pelotas. It remains to be elucidated if turtles may harbor leptospires and shed them in urine.

\section{ACKNOWLEDGEMENTS}

This work was supported by CNPq (Processo 558309/ 20089). The authors would like to thank Marco Antônio Coimbra from Departamento de Morfologia, Instituto de Biologia (UFPel), for technical assistance. É. F. S., N. S. and G. M. C. were supported by CAPES Foundation (Brazilian Government).

\section{RESUMO}

\section{Aglutininas séricas anti-leptospira em tartarugas de água doce no sul do Brasil}

Neste estudo, observamos a presença de aglutininas antiLeptospira em tartarugas de água doce de dois lagos urbanos de Pelotas, Sul do Brasil. Quarenta animais (29 Trachemys dorbigny e 11 Phrynops hilarii) foram capturados e estudados. Esforços para isolar leptospiras do sangue e urina não foram bem sucedidos. Amostras de soro positivas (títulos > 100), reativas para cepas patogênicas, foram observadas em 11 animais. Estes dados encorajam inquéritos para avaliação de tartarugas como potenciais transmissoras de leptospiras patogênicas para humanos.

Palavras-chave: Leptospirose, Tartarugas, Aglutininas

\section{REFERENCES}

1. Abdulla, P.K.; Karstad, L. (1962). Experimental infections with Leptospira pomona in snakes and turtles. Zoonos. Res., 1, 295-306.

2. Barcellos, C.; Lammerhirt, C.B.; Almeida, M.A.; Santos, E. (2003). Spatial distribution of leptospirosis in Rio Grande do Sul, Brazil: recovering the ecology of ecological studies. Cad. Saude Publica, 19 (5), 1283-1292.

3. Bharti, A.R.; Nally, J.E.; Ricaldi, J.N.; Matthias, M.A.; Diaz, M.M.; Lovett, M.A.; Levett, P.N.; Gilman, R.H.; Willig, M.R.; Gotuzzo, E.; Vinetz, J.M. (2003). Leptospirosis: a zoonotic disease of global importance. Lancet. Infect. Dis., 3 (12), 757-771.

4. Charon, N.W.; Johnson, R.C.; Muschel, L.H. (1975). Antileptospiral activity in lower-vertebrate sera. Infect. Immun., 12 (6), 1386-1391.

5. Faine, S.; Adler, B.; Bolin, C.; Perolat, P. (1999). Leptospira and leptospirosis, MediSci, Australia.

6. Faine, S.; Carter, J.N. (1968). Natural antibody in mammalian serum reacting with an antigen in some leptospires. J. Bacteriol., 95 (2), 280-285. 
7. Glosser, J.W.; Sulzer, C.R.; Eberhardt, M.; Winkler, W.G. (1974). Cultural and serologic evidence of Leptospira interrogans serotype Tarassovi infection in turtles. J. Wildl. Dis., 10 (4), 429-435.

8. Hyakutake, S.; de Biasi, P.; Santa Rosa, C.A.; Belluomni, H.E. (1976). Epidemiological study on leptospirosis in Brazilian snakes. Rev. Inst. Med. Trop. Sao Paulo, 18 (1), 10-16.

9. Johnson, R.C.; Muschel, L.H. (1965). Antileptospiral Activity of Normal Serum. J. Bacteriol., 89, 1625-1626.

10. McBride, A.J.; Athanazio, D.A.; Reis, M.G.; Ko, A.I. (2005). Leptospirosis. Curr. Opin. Infect. Dis., 18 (5), 376-386.

11. Salmonellosis associated with pet turtles-Wisconsin and Wyoming, 2004. 2005. MMWR Morb. Mortal. Wkly. Rep., 54 (9), 223-226. Available at: http:// www.cdc.gov/mmwr/preview/mmwrhtml/ mm5409a3.htm. Accessed 26 Fev 2009.
12. Santa Rosa, C.A.; Hyakutake, S.; Biasi, P.; Belluomini, H.E.; Kawarabayashi, M.; Godano, A. (1980). Contribuição ao estudo epidemiológico das leptospiroses em serpentes do Brasil: II. Levantamento sorológico em Crotalus durissus terrificus Laurenti 1768 (viperidae: crotalinae) - cascavel. Rev.Inst. Adolfo Lutz, 40, 9-13.

13. São Paulo Zoological Gardens Foundation. Tigre D’água. São Paulo. São Paulo Zoological Gardens Foundation. Available at: http:// www.zoologico.sp.gov.br/repteis/tigredagua.htm. Accessed 26Fev 2009.

14. Silva, É.F.; Brod, C.S.; Cerqueira, G.M.; Bourscheidt, D.; Seyffert, N.; Queiroz, A.; Santos, C.S.; Ko, A.I.; Dellagostin, O.A. (2007). Isolation of Leptospira noguchii from sheep. Vet. Microbiol., 121 (1-2), 144149.

15. Van Der Hoeden, J.; Szenberg, E.; Evenchik, Z. (1961). Leptospiraagglutinating factors in turtle sera. Nature, 190, 95-96. 